ISSN 1392-3196 / e-ISSN 2335-8947

Zemdirbyste-Agriculture, vol. 107, No. 1 (2020), p. 17-24

DOI $10.13080 /$ z-a.2020.107.003

\title{
The effect of plant-based organic fertilisers on the yield and nitrogen utilization of spring cereals in the organic cropping system
}

\author{
Monika TOLEIKIENE $\dot{1}^{1}$, Aušra ARLAUSKIENE² ${ }^{2}$, Lina ŠARŪNAITÉ ${ }^{1}$, \\ Gintare ŠIDLAUSKAITÉ ${ }^{1}$, Žydre KADŽIULIENE ${ }^{1}$ \\ ${ }^{1}$ Lithuanian Research Centre for Agriculture and Forestry, Institute of Agriculture \\ Instituto 1, Akademija, Kèdainiai distr., Lithuania \\ E-mail: monika.toleikiene@lammc.lt \\ ${ }^{2}$ Lithuanian Research Centre for Agriculture and Forestry, Joniškèlis Experimental Station \\ Karpių 1, Joniškèlis, Pasvalys distr., Lithuania
}

\begin{abstract}
Legumes in stockless cropping systems are the key elements for nitrogen $(\mathrm{N})$ supply, nutrient cycling, crop productivity and soil fertility. Field experiments were conducted in 2015-2017 on the loam and clay loam soil at two experimental locations in Lithuania. The aim of the research was to study the two-year effect of technologically processed plantbased organic fertilisers on the mineral $\mathrm{N}\left(\mathrm{N}_{\min }\right)$ and mobile humic substances in the soil, also the productivity and $\mathrm{N}$ accumulation by spring cereals in the organic cropping system. The following fertilisers were investigated: fresh mass of red clover, fermented red clover mass, fermented pea and wheat mass, composted red clover and wheat straw mass and granulated cattle manure. Fresh and fermented red clover mass was found to be rich in $\mathrm{N}$ and potassium (K), while composted red clover and straw mass was rich in phosphorus $(\mathrm{P})$. Soil $\mathrm{N}_{\min }$ was significantly increased by the fresh red clover mass in the $1^{\text {st }}$ experimental year and by fermented red clover mass in the $2^{\text {nd }}$ year, and significantly correlated with carbon to nitrogen ratio $(\mathrm{C}: \mathrm{N})$ of plant-based fertilisers. In the $1^{\text {st }}$ year, the grain yield of spring wheat was significantly increased using fresh red clover mass and granulated cattle manure; however, in the $2^{\text {nd }}$ year fermented red clover mass increased the yield of spring barley grain the most. During the two years of plant-based organic fertiliser use, in both experimental sites most of the $\mathrm{N}$ yield in cereal grains and straw was accumulated using fresh red clover, fermented red clover and granulated cattle manure fertilisers.

Comparison of the two experimental sites revealed that the effects of plant-based fertilisers on the productivity of cereals and changes in soil chemical compounds were more apparent in the $\mathrm{N}_{\min }$ low loam soil than in the $\mathrm{N}_{\text {min }}$ richer clay loam soil. The effect of fermented red clover and granulated cattle manure was comparable; however, greater improving effect was exhibited by the fermented red clover in the loam soil and by granulated cattle manure in the clay loam soil.
\end{abstract}

Key words: compost, C:N, fermented biomass, humus, red clover, soil.

\section{Introduction}

Significant technological progress has been achieved in the contemporary agriculture over the last decade; however, the reconciliation of requirements and expectations in the context of agro-ecosystem sustainability remains an essential challenge. The number of farmers operating stockless cropping systems has increased in many countries, although sustainable management of those systems is more complicated, especially in organic agriculture (Migliorini et al., 2014). Legumes in such cropping systems are key elements for biological nitrogen (N) supply and for decline of reliance on external inputs. As a result, legume-based cropping systems could provide ecological services in more sustainable ways (Crews, Peoples, 2005; Watson et al., 2017). On the other hand, the value of these services is greatly dependent on legume species, environmental conditions and management practises (Amossé et al., 2013; Pandey et al., 2017).

Recently, the effects of legumes on crop productivity, nutrient cycling and soil fertility have been investigated using them as the main crop (Šarūnaite et al., 2013; Povilaitis et al., 2016), pre-crop (Šarūnaite et al., 2013; Preissel et al., 2015), intercrop (Amossé et al., 2013; Arlauskienè et al., 2014), cover crop or green manure (Tripolskaja, Sidlauskas, 2010; ThorupKristensen et al., 2012; Brozyna et al., 2013; Li et al., 2015; Benke et al., 2017). Studies have shown that sometimes the incorporation of fresh legume mass with a high biologically fixed $\mathrm{N}$ content into the soil can have a negative impact on the environment because of the potential for $\mathrm{N}$ leaching (Tripolskaja, Sidlauskas, 2010; Valkama et al., 2015; De Notaris et al., 2018) and the nitrous oxide emissions (Brozyna et al., 2013; $\mathrm{Li}$ et al., 2015). Therefore, the technological processing of legume mass and its incorporation as plant-based organic amendment at the most appropriate time should be taken into account in order to maximise the nutrient use efficiency and mitigate any undesirable effects on the environment (Chen et al., 2018; De Notaris et al., 2018). Legumes have many advantages, so appropriate application of them can alleviate organic farming shortcomings and reduce the nutrient imbalances (Brock

Please use the following format when citing the article:

Toleikienė M., Arlauskienė A., Šarūnaitė L., Šidlauskaitė G., Kadžiulienė Ž. 2020. The effect of plant-based organic fertilisers on the yield and nitrogen utilization of spring cereals in the organic cropping system. Zemdirbyste-Agriculture, 107 (1): 17-24. DOI $10.13080 /$ z-a.2020.107.003 
et al., 2013; Möller, 2018). However, most utilization methods of legume biomass are limited in time, which is the reason for particular difficulties to meet the $\mathrm{N}$ needs of the main crop, especially of spring cereals (Doltra, Olesen, 2013; Möller, 2018; Räberg et al., 2018).

The synchrony between $\mathrm{N}$ available from organic resources via mineralization and the $\mathrm{N}$ demand of the crops in stockless farming systems is hard to achieve. The use of processed legume-based fertilisers could help to solve it at least in part, as the ensiling and fermentation of green aboveground biomass preserve most of the nutrients in the system and offer a possibility to decide the time for manure application (Sorensen, ThorupKristensen, 2011; Brock et al., 2013; Möller, 2018). This can also slow down the mineralization of organic fertilisers and improve the accumulation of organic matter in the soil (Brozyna et al., 2013; Carter et al., 2014). Fermentation of legume mass during ensiling is one of the most effective measures to reduce $\mathrm{N}$ losses (Carter et al., 2014; Benke et al., 2017), to avoid the accumulation of high $\mathrm{N}$ amount in just one field (Brozyna et al., 2013; van der Burgt et al., 2013; Carter et al., 2014) and to get the opportunity for the reallocation of nutrients to other fields (Räberg et al., 2018). Field experiments investigating the effects of differently processed legume mass are essential to assess the effects of fertility building measures both on crop productivity and soil nutrient dynamic (Benke et al., 2017; Doltra et al., 2019).

The aim of the present study was to explore the two-year effect of technologically processed plantbased organic fertilisers on the mineral $\mathrm{N}$ and mobile humic substances in the soil, also the productivity and $\mathrm{N}$ accumulation by spring cereals in a stockless organic cropping system.

\section{Materials and methods}

Experimental sites and soil. A study was conducted in 2015-2017 at two experimental sites of Lithuanian Research Centre for Agriculture and Forestry. The first site was established at Institute of Agriculture in Akademija $\left(55^{\circ} 24^{\prime} \mathrm{N}, 23^{\circ} 51^{\prime} \mathrm{E}\right)$, Kèdainiai district on a loam Endocalcaric Epigleyic Cambisol (Drainic, Loamic) (WRB, 2014), the second - at the Joniškèlis Experimental Station $\left(56^{\circ} 21^{\prime} \mathrm{N}, 24^{\circ} 10^{\prime} \mathrm{E}\right)$ on a clay loam Endocalcaric Endogleyic Cambisol (Clayic, Drainic) (WRB, 2014) (Table 1).

Table 1. The main characteristics of the experimental sites in $0-25 \mathrm{~cm}$ soil depth

\begin{tabular}{lcc}
\hline \multicolumn{1}{c}{ Parameters } & Akademija experimental site & Joniškèlis experimental site \\
\hline Soil group & Endocalcaric Epigleyic Cambisol & Endocalcaric Endogleyic Cambisol \\
Soil surface texture & loam & clay loam \\
Texture composition \% & 19.3 clay, 28.9 silt, 51.8 sand & 28.5 clay, 50.9 silt, 18.8 sand \\
Humus \% & $2.3 \pm 0.3$ & $3.0 \pm 0.4$ \\
$\mathrm{pH}$ & $7.5 \pm 0.5$ & $6.4 \pm 0.5$ \\
Available $\mathrm{P}_{2} \mathrm{O}_{5} \mathrm{mg} \mathrm{kg}^{-1}$ & $77 \pm 3$ & $173 \pm 3$ \\
Available $\mathrm{K}_{2} \mathrm{mg} \mathrm{kg}^{-1}$ & $137 \pm 3$ & $264 \pm 6$ \\
Bulk density $\mathrm{Mg} \mathrm{m}^{-3}$ & $1.40 \pm 0.5$ & $1.55 \pm 0.5$ \\
Total porosity $\%$ & $46 \pm 3$ & $41 \pm 1$ \\
\hline
\end{tabular}

Experimental treatments and design. The field experiment was conducted with crop rotation: red clover (Trifolium pratense L.) $\rightarrow$ common wheat (Triticum aestivum L. emend. Fiori et Paol.), winter form $\rightarrow$ common wheat, spring form $\rightarrow$ common barley (Hordeum vulgare L.), spring form. The following experimental design was conducted: 1) control with no fertilisers, 2) fresh red clovers (RC) mass, 3 ) fermented red clovers (FerRC) mass, 4) fermented pea and spring wheat $(\mathrm{FerP}+\mathrm{W})$ mass, $5)$ composted red clover and straw $(\mathrm{ComRC}+\mathrm{S})$ mass and 6) granulated cattle manure (GCM) for the comparison. The experimental plots were laid out in a complete onefactor randomized block design with four replicates. The individual plot size was $5 \times 12 \mathrm{~m}$.

Agronomic practises. Legume-based green fertilisers were produced from red clover mass (cut at the beginning of flowering stage), mixture of spring wheat and field pea (Pisum sativum L.) mass residues after harvest) and mixture of red clover and winter wheat straw mass (residues after harvest) using fermentation of silage and composting techniques in 2015 . The compost was piled on the $22^{\text {nd }}$ of June 2015 from the two main components: aboveground mass of red clover ( 3 parts) and winter wheat straw (1 part). Aerobic composting was performed stimulating the decomposition in the pile through mass remixing 5 times. After 10 months the compost was used as manure. The fermentation / ensiling of red clover or spring wheat and field pea mass was performed as follows: the mass was cut, chopped, piled into a special trench and then pressed well to minimise the access to air. Having completed the piling, the mass was hermetically sealed with a special film. All these processed fertilisers where incorporated into the soil in April 2016, except for fresh red clover mass, which was incorporated into the soil without processing in October 2015. To achieve better incorporation, red clover mass was chopped and incorporated by a disk cultivator at $10 \mathrm{~cm}$ depth before ploughing at $25 \mathrm{~cm}$ depth.

The efficiency of plant-based fertilisers was studied during the cultivation of spring wheat ('Vanek' seed rate $230 \mathrm{~kg} \mathrm{ha}^{-1}$ ) and spring barley ('Noja DS', seed rate $220 \mathrm{~kg} \mathrm{ha}^{-1}$ ). The crops were cultivated according to organic management practices using conventional tillage. The seedbed preparation was performed with a soil finisher / field cultivator shortly before seeding. Processed legumebased fertilisers were spread manually on the soil surface and incorporated into the soil $(0-15 \mathrm{~cm})$ before spring wheat sowing. A conventional sowing method was used. Grain yield was harvested when the majority of crops had reached hard dough stage (BBCH 87). Each experimental plot $($ size $2.3 \times 11.0 \mathrm{~m}$ ) was harvested with a small-plot combine harvester. After grain threshing, the yields were reported at $14 \%$ moisture. The experimental sites were managed with no use of mineral fertilisers and pesticides.

Plants and soil measurements. In the spring 2016, samples were taken from the prepared legumebased fertilisers to determine the chemical composition. Sampling of fresh red clover aboveground biomass was conducted prior to its incorporation into the soil in autumn 2015 (RC treatment). Total carbon $\left(\mathrm{C}_{\text {tot }}\right)$, total nitrogen $\left(\mathrm{N}_{\text {tot }}\right)$, total phosphorus $\left(\mathrm{P}_{\text {tot }}\right)$ and total potassium $\left(\mathrm{K}_{\mathrm{tot}}\right)$ were determined in the mass of red clover and other fertilisers. The rate of organic fertilisers to incorporate in the soil was calculated by the $\mathrm{N}_{\text {tot }}$ concentration and the dry matter (DM) weight of fertilisers, in order to supply no more than $3000 \mathrm{~kg} \mathrm{ha}^{-1} \mathrm{DM}$ and no more than $75 \mathrm{~kg} \mathrm{ha}^{-1}$ N. Grain and straw samples were taken at harvesting for the determination of DM and chemical analyses. Grains were analysed for: $\mathrm{N}$, straw - for $\mathrm{N}$ and $\mathrm{C}$ content. The concentrations of total $\mathrm{N}, \mathrm{P}$ and $\mathrm{K}$ were measured in the sulphuric acid digestates. Samples for $\mathrm{N}_{\text {tot }}$ determination were analysed using the Kjeldahl method with a Kjeltec system 1002 (Foss Tecator, Sweden). The concentrations of $\mathrm{P}_{\text {tot }}$ were quantified spectrophotometrically by a coloured reaction with ammonium molybdate-vanadate at a wavelength of $430 \mathrm{~nm}$ on a spectrophotometer Cary 50 UV-Vis (Varian Inc., USA). Respective $\mathrm{K}_{\text {tot }}$ concentrations were evaluated by atomic absorption spectrometry with an AAnalyst 200 (Perkin Elmer, USA) in accordance with the manufacturer's instructions. Soil samples for the determination of concentration (\% of soil DM) of mobile humic substances (MHS) and mobile humic acids (MHA) were collected from the $0-25 \mathrm{~cm}$ layer in the year of manure use. The samples for MHS and MHA were 
analysed spectrophotometrically using Carry 50 (Varian, Germany). Mineral nitrogen $\left(\mathrm{N}_{\min }\right)$ content in the 0-60 $\mathrm{cm}$ soil layer was measured in the spring $(2015,2016$ and 2017) before spring cereal sowing, determining the content of nitrate nitrogen $\left(\mathrm{NO}_{3}-\mathrm{N}\right) \mathrm{mg} \mathrm{kg}^{-1}$ of soil $\mathrm{DM}$ by ionometric and ammonium-nitrogen $\left(\mathrm{NH}_{4}-\mathrm{N}\right)-$ by spectrophotometric methods. Composite soil samples for $\mathrm{N}_{\text {min }}$ determination were taken from four drills of each plot.

Meteorological conditions. Weather data were collected at the meteorological stations located in Akademija and Joniškëlis experimental sites (Fig. 1). In 2016 , the temperature of vegetation period in both experimental sites was higher than the long-term average of 1980-2010. After cereal harvesting in 2016 the weather was close to long-term average. The winter period was relatively mild. The spring of 2017 started early. The air temperature of 2017 growing season differed little from the long-term average in both experimental sites. According to the weather data from the meteorological stations, the amount of precipitation was distributed very unevenly in 2016 and 2017. The spring in both locations in 2016 and 2017 was dryer compared with the standard climate norm. Precipitation in April and May was 1.9 and 5.3 times lower than the standard climate norm. However, the summers of

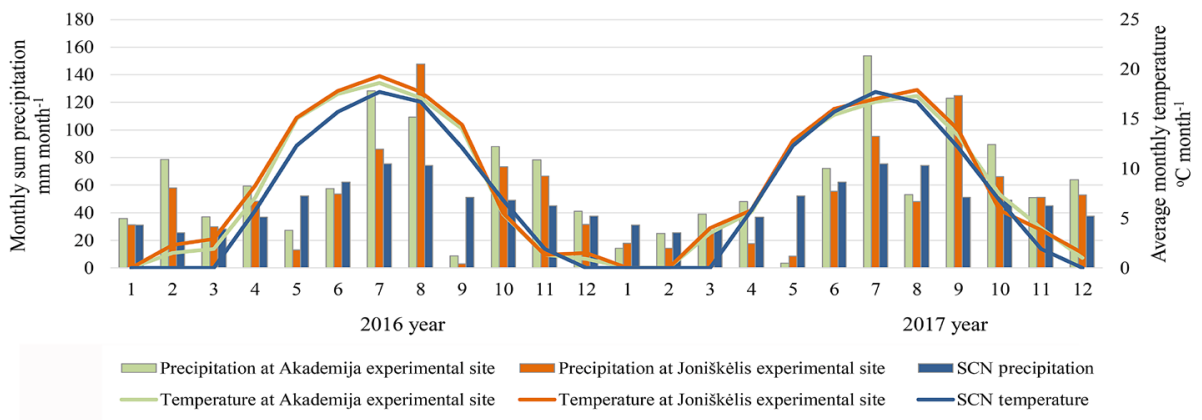

SCN - standard climate norm, average data for 30 years (1981-2010)

Figure 1. Monthly mean precipitation and temperature at the experimental sites

2016 and 2017 were unusually wet during the growing seasons, so the growth and development conditions for the spring barley were satisfactory.

Statistical analysis. The research data were statistically processed using a one-factor analysis of variance (ANOVA), correlation and regression methods (Raudonius, 2017). The experimental data were analysed when the factual Fisher criterion $\left(\mathrm{F}_{\text {fact. }}\right)$ was higher than the theoretical one $\left(\mathrm{F}_{\text {theor. }}\right)$. The significance of differences between the means (control and individual treatments) was estimated according to the least significant difference (LSD) at the 0.05 probability level. Interrelationships among the data were estimated separately for each location. A simple linear regression was applied. Correlation coefficients $(r)$ were calculated and presented in the results section.

\section{Results}

Chemical composition of organic manures. After technological processing of plant-based fertilisers, the concentration of $\mathrm{C}, \mathrm{N}, \mathrm{P}$ and $\mathrm{K}$ was found to be different in these fertilisers before their mass was incorporated into the soil. The lowest concentration of $\mathrm{C}$ and $\mathrm{N}$ was determined in the both fermented manures - red clover mass and pea and spring wheat mass (Table 2). The largest $\mathrm{N}$ amount was accumulated in the fresh red clover mass, composted red clover and straw mass $(\mathrm{ComRC}+\mathrm{S})$ and granulated cattle manure $(\mathrm{GCM})$. These fertilisers also contained higher amounts of $\mathrm{P}$ and $K$. The narrowest $C: P$ was found to be 76 for composted red clover and straw mass, and 81 for granulated cattle manure.

The amount of fertilisers applied to the field was fixed to supply 75,50 or $25 \mathrm{~kg} \mathrm{ha}^{-1} \mathrm{~N}$, in relation to the maximum weight of $3000 \mathrm{~kg} \mathrm{ha}^{-1} \mathrm{DM}$. Therefore, there was incorporated $1592-2632 \mathrm{~kg} \mathrm{ha}^{-1} \mathrm{DM}$ of organic fertilisers into the soil. The largest amount of organic matter was incorporated with green red clover mass and fermented fertilisers, the lowest amount of organic matter was present in the compost. The amount of nutrients incorporated with plant-based fertilisers: $\mathrm{N}$ varied from 25 to $75 \mathrm{~kg} \mathrm{ha}^{-1}, \mathrm{P}$ - from 4.1 to $10.8 \mathrm{~kg} \mathrm{ha}^{-1}$ and $\mathrm{K}$ - from 22.5 to $64.9 \mathrm{~kg} \mathrm{ha}^{-1}$. By adding the same amount of $\mathrm{N}$ with granulated cattle manure, more $\mathrm{P}$ and $\mathrm{K}$ were incorporated into the soil compared to the plantbased fertilisers.

Soil mineral nitrogen $\left(N_{\text {min }}\right)$ concentration in the clay loam soil was higher than that in the loam soil (11.23 and $8.03 \mathrm{mg} \mathrm{kg}^{-1}$ of soil, respectively) (Fig. 2). Because of the low $\mathrm{N}_{\min }$ concentration in the loam soil, the effect of fertilisers was more apparent in different years. In the loam soil, red clover fresh mass incorporated in autumn 2015 significantly increased the concentration of mineral and nitrate $\mathrm{N}$ (55.5\% and $57.6 \%$, respectively) compared to the control treatment. The other manures increased $\mathrm{N}_{\text {min }}$ content in $2^{\text {nd }}$ year, spring of 2017, but significantly highest amount was observed for fermented red clover mass. In the clay loam soil, the fertilisers only showed a tendency to increase the concentration of $\mathrm{N}_{\min }(9.1 \%)$ because of high $\mathrm{N}_{\min }$ concentration at the beginning of the vegetative season. However, fermented red clover mass also in the clay loam soil significantly increased $\mathrm{N}_{\min }$ in the $2^{\text {nd }}$ year (2017). The soil $\mathrm{N}_{\min }$ directly correlated with the $\mathrm{N}$ content of the incorporated organic fertiliser in both sites ( $r=0.64$ and $r=0.61, p<0.05$, respectively).

The major share of $\mathrm{N}_{\min }(72.7-79.6 \%)$ consisted of nitrate-nitrogen $\left(\mathrm{NO}_{3}-\mathrm{N}\right)$ and only a small amount of ammonium-nitrogen $\left(\mathrm{NH}_{4}-\mathrm{N}\right)$ and did not show significant differences between treatments. In the $2^{\text {nd }}$

Table 2. The amount of nutrients accumulated in the organic fertilisers and incorporated into the soil

\begin{tabular}{|c|c|c|c|c|c|c|c|c|c|}
\hline \multirow{2}{*}{$\begin{array}{c}\text { Plant-based } \\
\text { organic fertilisers }\end{array}$} & \multicolumn{4}{|c|}{ Accumulated $\mathrm{kg} \mathrm{t}^{-1} \mathrm{DM}$} & \multicolumn{4}{|c|}{ Incorporated $\mathrm{kg} \mathrm{ha}^{-1} \mathrm{DM}$} & \multirow{2}{*}{$\mathrm{C}: \mathrm{N}, \mathrm{C}: \mathrm{P}, \mathrm{C}: \mathrm{K}$} \\
\hline & $\mathrm{C}$ & $\mathrm{N}$ & $\mathrm{P}$ & $\mathrm{K}$ & mass & $\mathrm{N}$ & $\mathrm{P}$ & $\mathrm{K}$ & \\
\hline Control & - & - & - & - & 0 & 0 & 0 & 0 & \\
\hline $\mathrm{RC}$ & 520 & 33.4 & 2.6 & 28.6 & 2269 & 75 & 6.0 & 64.9 & $15,200,18$ \\
\hline FerRC & 392 & 19.0 & 1.9 & 17.2 & 2632 & 50 & 5.0 & 45.3 & $21,206,23$ \\
\hline $\mathrm{FerP}+\mathrm{W}$ & 378 & 10,8 & 1.8 & 9.9 & 2273 & 25 & 4.1 & 22.5 & $35,210,38$ \\
\hline ComRC $+\mathrm{S}$ & 514 & 31.4 & 6.8 & 30.1 & 1592 & 50 & 10.8 & 47.9 & $16,76,17$ \\
\hline GCM & 469 & 27.6 & 5.8 & 45.2 & 1812 & 50 & 10.6 & 81.8 & $17,81,10$ \\
\hline
\end{tabular}

$\mathrm{RC}-$ fresh red clover mass, FerRC - fermented red clover mass, FerP $+\mathrm{W}-$ fermented pea and spring wheat mass, ComRC $+\mathrm{S}-$ composted red clover and straw mass, GCM - granulated cattle manure; DM - dry matter 

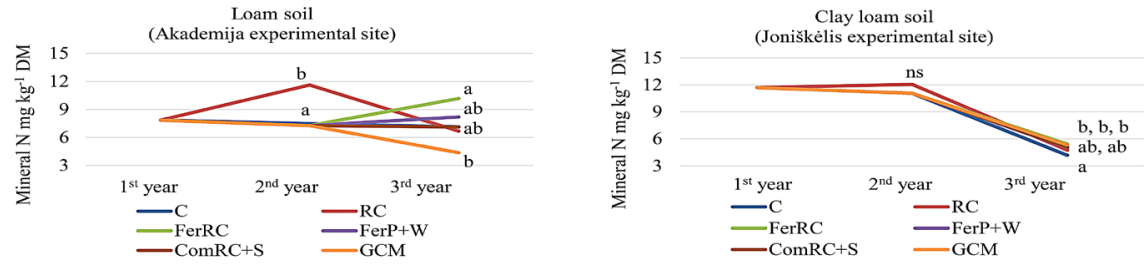

Note. Explanations under Table 2; different letters indicate statistically significant differences between the treatments $(p<0.05)$; ns - differences are not significant.

Figure 2. Mineral nitrogen $(\mathrm{N})$ content in the $0-60 \mathrm{~cm}$ soil depth in a 3-year crop rotation before and after plant-based organic fertiliser incorporation

year after fertiliser application (2017), the concentration of $\mathrm{N}_{\min }$ in the soil depended on the incorporated organic fertiliser DM mass and its C:N $(r=0.81, p<0.01$ and $r=0.65, p<0.05$, respectively) in clay loam soil, while the correlation was weak and insignificant in loam soil. The use of fermented red clover mass, composted manure and granulated cattle manure significantly increased the concentration of $\mathrm{N}_{\min }$ and $\mathrm{NO}_{3}-\mathrm{N}$ and the ratio of $\mathrm{NO}_{3}-\mathrm{N}$ and $\mathrm{NH}_{4}-\mathrm{N}$ in the clay loam soil (Fig. 3). The $\mathrm{NO}_{3}^{3}-\mathrm{N}$ concentration in loam soil increased significantly only by fermented red clover mass.

Cereals yield. According to the averaged data, the spring wheat grain yield was higher in clay loam soil (3416 $\left.\mathrm{kg} \mathrm{ha}^{-1} \mathrm{DM}\right)$ compared with that in loam soil (2039 kg ha-1 DM) (Table 3). In loam soil, the fresh red clover mass incorporated in the autumn, granulated cattle manure and compost incorporated in the spring before cereal sowing significantly increased the spring wheat grain yield (28.0, 17.0 and $10.2 \%$, respectively) compared to the control treatment. In clay loam soil, the differences were not found comparing different fertilisers with the control, but significantly higher grain yield was accumulated using fresh red clover mass and granulated cattle manure than using fermented and composted plant-based manures. In both experimental sites, the grain yield depended on the chemical composition of incorporated plant-based fertilisers and significantly correlated with the amount of added $\mathrm{N}_{\text {tot }}$ and the $\mathrm{N}_{\text {min }}$ content in the soil $(r=0.81, r=0.73, p<0.01$ and $r=0.44, r=0.55, p<0.05$, respectively). In both experimental sites, the use of green fertilisers substantially increased the spring wheat straw yield, while in clay loam soil the straw yield was significantly lower followed by the use of fermented red clover.

In the $2^{\text {nd }}$ year, the spring barley grain yield was significantly higher than in the control when using fresh and fermented red clover mass, $12.2 \%$ and $11.8 \%$, respectively in loam soil. Similar high efficiency of fermented red clover mass was determined in clay loam soil, while the efficiency of used fresh red clover mass was not higher. In clay loam soil, a positive linear dependence of spring barley grain yield on soil $\mathrm{N}_{\min }$ was determined $(r=0.77, p<0.05)$. In loam soil, the significant differences of the spring barley straw yield due to the use of different fertilisers were not observed. Conversely, in the clay loam soil, significantly lower straw yields were obtained by using fertilisation with fresh red clover mass compared to fermented mass or granulated cattle manure. In most cases weed mass did not differ significantly using different plant-based fertilisers, except for fresh red clover mass, which increased the weed incidence in the $2^{\text {nd }}$ year after application in the clay loam soil. This was also related to low productivity of spring barley in

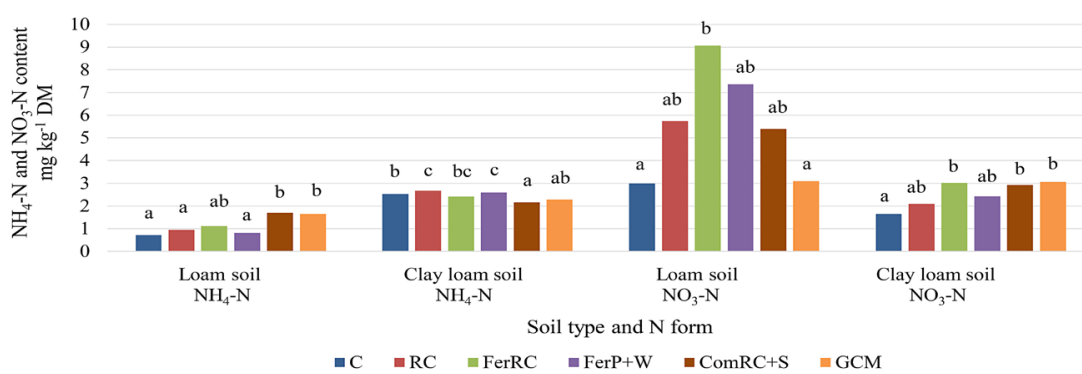

Note. Explanations under Table 2; different letters indicate statistically significant differences between the treatments $(p<0.05)$.

Figure 3. Ammonium-nitrogen $\left(\mathrm{NH}_{4}-\mathrm{N}\right)$ and nitrate-nitrogen $\left(\mathrm{NO}_{3}-\mathrm{N}\right)$ content in the $0-60 \mathrm{~cm}$ soil depth in the spring of the $2^{\text {nd }}$ year after plant-based organic fertilisers incorporation

Table 3. The influence of various organic manures on cereal yield

\begin{tabular}{|c|c|c|c|c|c|c|}
\hline \multirow{3}{*}{$\begin{array}{l}\text { Plant-based } \\
\text { organic } \\
\text { fertilisers }\end{array}$} & \multicolumn{3}{|c|}{ Spring wheat, 2016} & \multicolumn{3}{|c|}{ Spring barley, 2017} \\
\hline & grain yield & straw yield & weed mass & grain yield & straw yield & weed mass \\
\hline & \multicolumn{6}{|c|}{$\mathrm{kg} \mathrm{ha}^{-1} \mathrm{DM}$} \\
\hline \multicolumn{7}{|c|}{ Loam soil (Akademija experimental site) } \\
\hline Control & $1877 \mathrm{~b}$ & $2335 \mathrm{a}$ & $111 \mathrm{ab}$ & $2028 \mathrm{a}$ & $1330 \mathrm{ab}$ & $109 \mathrm{ab}$ \\
\hline $\mathrm{RC}$ & $2401 \mathrm{e}$ & $3195 \mathrm{~b}$ & $147 \mathrm{ab}$ & $2276 \mathrm{c}$ & $1401 \mathrm{ab}$ & $85 \mathrm{ab}$ \\
\hline FerRC & $1966 \mathrm{bc}$ & $2524 \mathrm{a}$ & $188 \mathrm{ab}$ & $2268 \mathrm{bc}$ & $1357 \mathrm{ab}$ & $125 \mathrm{ab}$ \\
\hline FerP $+W$ & $1730 \mathrm{a}$ & $2421 \mathrm{a}$ & $191 \mathrm{~b}$ & $2139 \mathrm{abc}$ & $1510 \mathrm{~b}$ & $138 \mathrm{~b}$ \\
\hline ComRC+S & $2067 \mathrm{~cd}$ & $2305 \mathrm{a}$ & $120 \mathrm{ab}$ & $2224 \mathrm{abc}$ & $1409 \mathrm{ab}$ & $134 \mathrm{ab}$ \\
\hline GCM & $2196 \mathrm{~d}$ & 2242 a & $180 \mathrm{ab}$ & $2235 \mathrm{abc}$ & $1499 \mathrm{ab}$ & $136 \mathrm{ab}$ \\
\hline Mean & 2039 & 2503 & 156 & 2195 & 1418 & 121 \\
\hline \multicolumn{7}{|c|}{ Clay loam soil (Joniškèlis experimental site) } \\
\hline Control & 3391 abcd & 2818 abc & $244 \mathrm{ab}$ & $2450 \mathrm{ab}$ & $2395 \mathrm{abc}$ & $226 \mathrm{ab}$ \\
\hline $\mathrm{RC}$ & $3644 \mathrm{bcd}$ & $3033 \mathrm{c}$ & $167 \mathrm{ab}$ & $2360 \mathrm{a}$ & $2248 \mathrm{a}$ & $359 \mathrm{~d}$ \\
\hline FerRC & $3246 \mathrm{a}$ & $2953 \mathrm{abc}$ & $282 \mathrm{ab}$ & $2887 \mathrm{~d}$ & $2667 \mathrm{bc}$ & $330 \mathrm{bcd}$ \\
\hline $\mathrm{FerP}+\mathrm{W}$ & 3239 a & $2750 \mathrm{a}$ & $248 \mathrm{ab}$ & $2496 \mathrm{ab}$ & $2459 \mathrm{abc}$ & 281 abcd \\
\hline $\mathrm{ComRC}+\mathrm{S}$ & $3283 \mathrm{ab}$ & $2918 \mathrm{abc}$ & $263 \mathrm{ab}$ & $2665 \mathrm{bcd}$ & $2467 \mathrm{abc}$ & $225 \mathrm{ab}$ \\
\hline GCM & $3695 \mathrm{~d}$ & $2932 \mathrm{abc}$ & $316 \mathrm{~b}$ & $2713 \mathrm{bcd}$ & $2692 \mathrm{c}$ & $208 \mathrm{a}$ \\
\hline Mean & 3416 & 2901 & 253 & 2595 & 2488 & 271 \\
\hline
\end{tabular}

Note. Explanations under Table 2; different letters indicate statistically significant differences between the treatments $(p<0.05)$. 
that treatment under fresh clover fertilisation. The overall mean productivity of the cenosis was higher in the clay loam soil than in loam soil.

Accumulation of nitrogen $(N)$ in cereal yield. In the $1^{\text {st }}$ year after fertilisation, the concentration of $\mathrm{N}_{\text {tot }}$ in spring wheat grains significantly increased $(0.7$ $\left.1.7 \mathrm{~g} \mathrm{~kg}^{-1}\right)$ by applying fresh red clover mass, fermented red clover mass and granulated cattle manure compared to the control, in the loam soil (Table 4), whereas there were no significant differences between treatments in clay loam soil. The concentration of $\mathrm{N}$ in spring wheat straw was significantly influenced by the fresh red clover mass and both fermented fertilisers compared to the control in a loam soil, but there was no significant positive impact in clay loam soil.

In the $2^{\text {nd }}$ year after fertilisation, the fresh red clover mass and both fermented fertilisers had a significant impact on $\mathrm{N}$ content in spring barley grains in loam soil. In clay loam soil, the significant influence of fermented red clover and granulated cattle manure on $\mathrm{N}$ content in spring barley grains was found. In clay loam soil, the efficiency of granulated cattle manure

Table 4. The influence of various organic manures on nitrogen $(\mathrm{N})$ concentration in cereal grain and straw yield

\begin{tabular}{|c|c|c|c|c|c|c|c|c|}
\hline \multirow{4}{*}{$\begin{array}{c}\text { Plant-based } \\
\text { organic } \\
\text { fertilisers }\end{array}$} & \multicolumn{4}{|c|}{$\begin{array}{c}\text { Loam soil } \\
\text { (Akademija experimental site) }\end{array}$} & \multicolumn{4}{|c|}{$\begin{array}{c}\text { Clay loam soil } \\
\text { (Joniškèlis experimental site) }\end{array}$} \\
\hline & \multicolumn{2}{|c|}{ spring wheat } & \multicolumn{2}{|c|}{ spring barley } & \multicolumn{2}{|c|}{ spring wheat } & \multicolumn{2}{|c|}{ spring barley } \\
\hline & grain & straw & grain & straw & grain & straw & grain & straw \\
\hline & \multicolumn{8}{|c|}{$\mathrm{Ng} \mathrm{kg}{ }^{-1} \mathrm{DM}$} \\
\hline Control & $14.5 \mathrm{a}$ & $3.5 \mathrm{a}$ & $15.8 \mathrm{abc}$ & $6.3 \mathrm{abc}$ & $15.6 \mathrm{abc}$ & $3.5 \mathrm{cde}$ & $11.1 \mathrm{ab}$ & $2.7 \mathrm{a}$ \\
\hline $\mathrm{RC}$ & $16.2 \mathrm{e}$ & $4.8 \mathrm{~d}$ & $15.5 \mathrm{a}$ & $5.9 \mathrm{abc}$ & $16.0 \mathrm{c}$ & $3.6 \mathrm{e}$ & $11.0 \mathrm{a}$ & $3.0 \mathrm{abc}$ \\
\hline FerRC & $15.2 \mathrm{bc}$ & $3.7 \mathrm{~b}$ & $16.4 \mathrm{c}$ & $6.6 \mathrm{c}$ & $15.1 \mathrm{a}$ & $3.1 \mathrm{a}$ & $11.8 \mathrm{c}$ & $3.2 \mathrm{bc}$ \\
\hline FerP $+W$ & $15.1 \mathrm{abc}$ & $4.1 \mathrm{c}$ & $16.4 \mathrm{bc}$ & $6.3 \mathrm{abc}$ & $15.2 \mathrm{a}$ & $3.2 \mathrm{a}$ & $11.5 \mathrm{abc}$ & $3.1 \mathrm{abc}$ \\
\hline $\mathrm{ComRC}+\mathrm{S}$ & $14.6 \mathrm{ab}$ & $3.7 \mathrm{ab}$ & $15.8 \mathrm{abc}$ & $5.5 \mathrm{a}$ & $15.2 \mathrm{a}$ & $3.2 \mathrm{ab}$ & $11.1 \mathrm{ab}$ & $3.2 \mathrm{bc}$ \\
\hline GCM & 15.4 cde & $3.6 \mathrm{ab}$ & $15.8 \mathrm{abc}$ & $6.2 \mathrm{abc}$ & $15.5 \mathrm{abc}$ & $3.4 \mathrm{bc}$ & $11.8 \mathrm{c}$ & $3.0 \mathrm{abc}$ \\
\hline Mean & 15.2 & 3.9 & 15.9 & 6.1 & 15.4 & 3.4 & 11.4 & 3.0 \\
\hline
\end{tabular}

Note. Explanations under Table 2; different letters indicate statistically significant differences between the treatments $(p<0.05)$.

was similar to that of the fermented red clover mass and both fertilisers increased the $\mathrm{N}$ concentration in spring barley grains compared to the fresh red clover mass. In loam soil, the $\mathrm{N}$ concentration in spring barley straw was the highest when fermented red clover mass was used compared only to compost. In clay loam soil, significantly higher $\mathrm{N}$ concentrations compared to the control were accumulated in spring barley straw by using fermented red clover mass and compost.

The tendencies of $\mathrm{N}_{\text {tot }}$ accumulation in cereal harvest (grains + straw) differed between years and locations (Fig. 4). In the loam soil, the accumulated $\mathrm{N}_{\text {tot }}$ was substantially increased by all organic fertilisers in both years. In the $1^{\text {st }}$ year, the significantly highest effect on spring barley was found when using fresh red clover mass, which also increased the $\mathrm{N}_{\text {tot }}$ accumulated during two years. During two experimental years, also the higher $\mathrm{N}$ amount in cereal yield was accumulated by fertilising with fermented red clover mass and granulated cattle manure. The N content was increased by $29.5 \%$ and $13.2 \%$, respectively compared to the control (unfertilised treatment).
In the clay loam soil, the $\mathrm{N}_{\text {tot }}$ accumulated in the spring wheat yield was increased by the fresh red clover mass and granulated cattle manure, while in the spring barley - by the fermented red clover mass and granulated cattle manure (the differences are significant compared to the control). However, the efficiency of organic fertilisers in the clay loam soil was lower than in the loam soil. In total, the fresh red clover and fermented red clover fertilisers increased the accumulated $\mathrm{N}_{\text {tot }}$ content by $5.7 \%$ and $4.6 \%$, respectively, and the granulated cattle manure - by $11.3 \%$ compared to the control.

Similarities were found in both experimental sites: the effect on cereals $\mathrm{N}_{\text {tot }}$ yield was positive and did not differ between fermented red clover mass and granulated cattle manure; the higher efficiency of the fresh red clover mass was found in the $1^{\text {st }}$ year and the higher efficiency of the fermented red clover mass was obtained in the $2^{\text {nd }}$ year.

Mobile humic substances (MHS) and mobile humic acids $(\boldsymbol{M H} \boldsymbol{A})$. In the year of use of organic fertilisers, the change of MHS and mobile humic acids (MHA) in the

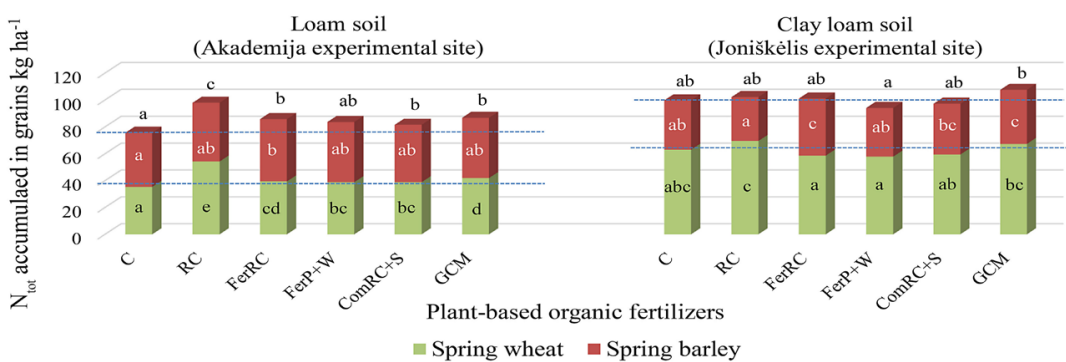

Note. Explanations under Table 2; different letters indicate statistically significant differences between the treatments $(p<0.05)$.

Figure 4. The influence of plant-based organic fertilisers on the total nitrogen $\left(\mathrm{N}_{\text {tot }}\right)$ accumulation in cereal grains and straw yield

top soil layer $(0-10 \mathrm{~cm})$ was determined after spring wheat harvesting. The study showed that loam soil was richer in MHS and MHA than clay loam soil (Table 5).

In loam soil, the highest MHS concentration was found in the compost and control (unfertilised) treatments. The values of this indicator substantially decreased after the use of fresh red clover mass, fermented red clover mass and granulated cattle manure compared to the unfertilised control treatment. In clay loam soil, the granulated cattle manure substantially increased the MHS concentration, and the fermented field pea and spring wheat mixture mass tend to increase this indicator compared to the control. The lowest MHS concentration was found after incorporation of the fresh red clover mass, but a low significance of differences was shown.
In both experimental sites, the lowest MHA values were found in the soil after the fresh red clover mass was used (in clay loam soil, the fermented pea and spring wheat mass showed similar MHA as the fresh red clover mas), the highest - after the granulated cattle manure. In loam soil, the concentration of MHS significantly declined $(r=-0.79, p<0.01)$ by increasing the $\mathrm{N}$ amount with organic fertilisers (from 25 to $\left.75 \mathrm{~kg} \mathrm{ha}^{-1}\right)$. The MHS concentration depended on the $\mathrm{C}: \mathrm{N}$ of incorporated organic fertilisers. Also, the MHS concentration increased from 16 to 35 when MHA concentration increased $(r=0.56, p<0.05)$ in the soil. In clay loam soil, the relations between these indicators were not significant. Similar trends were identified in this experimental site. In both experimental sites, the soil 
Table 5. The influence of various organic manures on the variation of mobile humic substances (MHS) and mobile humic acids (MHA) in the $0-10 \mathrm{~cm}$ soil layer

\begin{tabular}{|c|c|c|c|c|}
\hline \multirow{3}{*}{$\begin{array}{c}\text { Plant-based } \\
\text { organic fertilisers }\end{array}$} & \multicolumn{2}{|r|}{$\begin{array}{c}\text { Loam soil } \\
\text { (Akademija experimental site) }\end{array}$} & \multicolumn{2}{|c|}{$\begin{array}{c}\text { Clay loam soil } \\
\text { (Joniškèlis experimental site) }\end{array}$} \\
\hline & MHS & MHS & MHA & \\
\hline & \multicolumn{4}{|c|}{$\%$ of soil DM } \\
\hline Control & $0.294 \mathrm{~cd}$ & $0.138 \mathrm{ab}$ & $0.186 \mathrm{a}$ & $0.076 \mathrm{bcd}$ \\
\hline $\mathrm{RC}$ & $0.265 \mathrm{a}$ & $0.134 \mathrm{a}$ & $0.176 \mathrm{a}$ & $0.058 \mathrm{a}$ \\
\hline FerRC & $0.277 \mathrm{~b}$ & $0.142 \mathrm{abcd}$ & $0.179 a$ & $0.060 \mathrm{a}$ \\
\hline FerP+W & $0.279 \mathrm{~b}$ & $0.150 \mathrm{bcd}$ & $0.189 \mathrm{abc}$ & $0.070 \mathrm{ab}$ \\
\hline $\mathrm{ComRC}+\mathrm{S}$ & $0.286 \mathrm{bcd}$ & $0.140 \mathrm{abcd}$ & $0.178 \mathrm{a}$ & $0.058 \mathrm{a}$ \\
\hline GCM & $0.280 \mathrm{~b}$ & $0.153 \mathrm{~d}$ & $0.208 \mathrm{c}$ & $0.092 \mathrm{~d}$ \\
\hline Mean & 0.282 & 0.143 & 0.186 & 0.069 \\
\hline
\end{tabular}

Note. Explanations under Table 2; different letters indicate statistically significant differences between the treatments $(p<0.05)$.

mobile humic materials MHS and MHA correlated with the soil $\mathrm{N}$ significantly negatively $(r=-0.80, p<0.01$ $r=-0.62, p<0.05$ and $r=-0.41, p<0.05 ; r=-0.40$, $p<0.05$, in loam and clay loam soils respectively).

\section{Discussion}

The chemical composition of plant-based organic fertilisers. Plant nutrition in arable farms can be enriched by using organic fertilisers, although their function and the satisfaction of crop demand are highly dependent on the type or chemical composition (Chen et al., 2018; Žydelis et al., 2019). The fresh red clover mass can accumulate a high $\mathrm{N}$ amount (Brozyna et al., 2013; Frøseth et al., 2014; Gaudin et al., 2013), but the process of $\mathrm{N}$ accumulation and release is difficult to predict and control. The chemical composition of the plant-based organic fertilisers depends on the quality of plant raw materials used and the methods of plant mass processing. In this research, the lower losses of organic matter and nutrients were obtained by fermentation of red clover mass. The similar losses of biomass during legumegrass mixtures ensiling (fermentation) were also reported in other studies (Sørensen et al., 2013). In stockless organic farming systems, $\mathrm{P}$ is an essential plant nutrient as well. The highest amount of $\mathrm{P}$ was found in composted pea and wheat mass and granulated cattle manure. All investigated plant-based organic fertilisers were rich in $\mathrm{K}$ (except for the fermented field pea and spring wheat mixture mass). References indicate that organic fertilisers based on legume plants have a balanced spectrum of nutrients, suitable for plant fertilisation (Frøseth et al., 2014; Möller, 2018). Nutrient utilization from fertilisers also depends on the $\mathrm{C}: \mathrm{N}$. The lowest $\mathrm{C}: \mathrm{N}$ was found in the fresh red clover mass, the highest - in the fermented field pea and spring wheat mixture mass (15 and 35, respectively).

C:N of plant-based fertilisers and its influence on soil $\boldsymbol{N}_{\text {min }}$. Studies show that legume sward mass is rapidly degraded in the soil due to the high $\mathrm{N}$ content $(>2.5 \%)$ and narrow $\mathrm{C}: \mathrm{N}(<20)$. This does not guarantee effective N-uptake (van Opheusden et al., 2012; Doltra, Olesen, 2013). The intensity and duration of the organic fertilisers incorporation into the soil can be attributed to soil $\mathrm{N}_{\min }$ and $\mathrm{N}$ accumulation in cereal yield. Rapid decomposition of fresh red clover mass was demonstrated by increased $\mathrm{N}_{\min }$ content in the soil, $\mathrm{N}$ concentration in spring wheat grains during the $1^{\text {st }}$ year and $\mathrm{N}$ content decreased in the $2^{\text {nd }}$ year after fertiliser application. Red clover and lucerne biomass can accumulate high $\mathrm{N}$ content; therefore, it significantly increased the amount of soil $\mathrm{N}_{\min }$ in late autumn after sward ploughing (Nemeikšiene et al., 2010; Sarūnaitè et al., 2013). van Opheusden et al. (2012) indicate that organic fertilisation with a very high mineralization rate leads to a significant increase in $\mathrm{N}_{\min }$ content in the soil over the course of the year. The content of $\mathrm{N}_{\min }$ can be better managed by including catch crops, controlling the fertilisation and residue management in clay loam soil (Arlauskienè et al., 2019). For example, the use of fertilisers with medium (manure) or low (plant compost) mineralization over time ( $4-5$ years) increases soil organic matter accumulation. In our research, fermented fertilisers $(\mathrm{C}: \mathrm{N}=21$ and 35$)$ decomposed more slowly (especially in clay loam soil); therefore, increasing of soil $\mathrm{N}_{\min }$ and $\mathrm{N}$ concentration in cereal grain was found in $2^{\text {nd }}$ year after the fertiliser application.

Similar data were obtained by using granulated cattle manure. There is little research on the decomposition and mineralisation of fermented plant mass. It is claimed that due to low $\mathrm{NH}_{4} \mathrm{~N}$ and low fertiliser $\mathrm{pH}$, the risk of gas losses is weak (Benke et al., 2017); therefore, more available $\mathrm{N}$ is generated for plants (Carter et al., 2014; Möller, 2018). Granulated cattle manure after incorporation into the soil alters in the chemical composition, because easily degradable organic substances are fragmented and form more stable organic compounds compared to fermented and fresh organic fertilisers.

Compost also decomposes slowly in the soil, only a small fraction (10-15\%) of its mass decomposes per year (van Opheusden et al., 2012). The concentrations of soil $\mathrm{N}_{\min }$ and its forms (ammonium and nitrate) depend on soil texture, weather conditions, farming method and quality of organic fertilisers used. During the two years of study (2016 and 2017), high precipitation occurred after fertiliser incorporation and this could accelerate $\mathrm{N}$ mineralisation in the soil and contribute to higher yields in the treatments amended with narrow $\mathrm{C}: \mathrm{N}$ as fresh and fermented red clover mass and granulated cattle manure. The different mineralisation in the two types of soil could be affected by unequal soil microbial community, enzyme activity, and decomposition and stabilisation rates of incorporated organic material (Rong et al., 2018).

Spring cereal yield and $N$ accumulation in grains. In the year of fertiliser incorporation (2016), the spring wheat grain yield increased due to the addition of $\mathrm{N}$ with the fertiliser and higher content of $\mathrm{N}_{\min }$ in the soil. The spring wheat yield was increased by the fresh red clover mass and granulated cattle manure. Using the fermented field pea and spring wheat mixture mass for fertilisation decreased the spring wheat grain yield. The losses of spring wheat grain yield resulted from decrease in soil $\mathrm{N}_{\min }$ due to expected $\mathrm{N}$ immobilization in soil organic material. This process was stimulated by lower $\mathrm{N}$ content and high $\mathrm{C}: \mathrm{N}$ of organic fertilisers. Therefore, plant-based biomass management can in various ways affect the $\mathrm{N}$ supply for following crops and ultimate crop yield and quality (Doltra, Olesen, 2013; Grant et al., 2016).

On the other hand, in the $2^{\text {nd }}$ year of fertiliser usage the spring barley grain yield tended to increase when using fermented red clover mass. The higher $\mathrm{N}$ concentration in cereal grain was obtained in loam soil. The fermented red clover mass (which substantially increased the grain yield during the $2^{\text {nd }}$ year in both experimental sites) proved the longer-lasting ecosystem maintenance. Möller (2018) has noted that additionally processed legume and grass mixture mass can be used as a long-lasting fertiliser. Our research showed that using fermented legume mass can produce similar cereal yields as granulated cattle manure. According to other researchers (Olesen et al., 2007; Benke et al., 2017), the fertiliser efficiency and its duration depend on its chemical composition and application time. $\mathrm{N}$ accumulation in grain yield depends on the factors already mentioned in this paper, but it may also depend 
on the species and variety of cereals, their needs for $\mathrm{N}$ (Crews, Peoples, 2005; Nkurunziza et al., 2017).

Legume-based fertilisers and carbon $(C)$. Labile soil organic matter provides more information on short-term soil organic carbon (SOC) changes than humus (Fortuna et al., 2003; Brock et al., 2013). The chemical composition of the plant-based organic fertilisers affects soil organic matter (SOM) and the changes depend on C:N (Dannehl et al., 2017).

In this study was showed that the incorporated $\mathrm{N}$ amount and $\mathrm{C}: \mathrm{N}$ influenced the changes of MHS and MHA concentrations. If the fresh red clover mass reduced the mobile humus amount, the fermented fertiliser with wider $\mathrm{C}: \mathrm{N}$ increased the MHA amount. In both experimental sites, the soil mobile organic matter decreased in line with the increases in soil $\mathrm{N}_{\min }$ concentration (the mineralization of the incorporated organic fertiliser increased). The higher content of MHA in the SOM makes it more stable, slows down its mineralization and inhibits soil chemical degradation. Therefore, it contributes to the preservation of nutrients and macro-elements in the topsoil (Volungevičius et al., 2019).

\section{Conclusions}

1. Plant-based organic fertilisers were rich in nitrogen $(\mathrm{N})$ and potassium $(\mathrm{K})$, while red clover and straw compost had more phosphorus $(\mathrm{P})$. The nutrient ratio in fertilisers was favourable for cereals. The release of nutrients from fertilisers depended on the carbon to nitrogen ratio $(\mathrm{C}: \mathrm{N})$, which was the highest for fresh red clover mass and the lowest for the fermented field pea and spring barley mixture mass

2. The variation of soil mineral nitrogen $\left(\mathrm{N}_{\min }\right)$ content depended on the $\mathrm{N}$ amount and $\mathrm{C}: \mathrm{N}$ of the organic fertiliser. In the $1^{\text {st }}$ year, the incorporated fresh red clover mass increased $\mathrm{N}_{\min }$ in the loam soil by $55.5 \%$ and in the clay loam soil by $9.1 \%$ compared to the control. In the $2^{\text {nd }}$ experimental year, the fermented red clover mass, compost and granulated cattle manure significantly increased the $\mathrm{N}_{\min }$ concentration. The negative correlation was found between $\mathrm{N}_{\min }$ and mobile humic substances in the soil.

3. In the loam soil, during the years of fertiliser influence the spring wheat yield was significantly increased by the incorporation of fresh red clover mass and granulated cattle manure. In the clay loam, the similar trends were obtained in cereal yield parameters. In the $2^{\text {nd }}$ year after fertiliser usage, the spring barley grain yield was significantly increased by fermented red clover mass in the both experimental sites.

4. During the two years of organic fertiliser influence, the highest accumulated $\mathrm{N}$ content in the total spring wheat and spring barley yield (grain and straw) was found after incorporation of the fresh and fermented red clover mass and granulated cattle manure. Amendment with the fermented legume mass can produce similar yields as amendment with the granulated cattle manure.

Received 17072019

Accepted 25112019

\section{References}

1. Amossé C., Jeuffroy M.-H., David C. 2013. Relay intercropping of legume cover crops in organic winter wheat: Effects on performance and resource availability. Field Crops Research, 145: 78-87.

https://do1.org/10.1016/j.fcr.2013.02.010

2. Arlauskienè A., Sarūnaitè L., Kadžiulienè Ž., Deveikytè I., Maikštenienè S. 2014. Suppression of annual weeds in pea and cereal intercrops. Agronomy Journal, 106 (5): 1765-1774. https://doi.org/10.2134/agronj13.0478

3. Arlauskienè A., Cesevičienè J., Velykis A. 2019. Improving mineral nitrogen control by combining catch crops, fertilisation, and straw management in a clay loam soil. Acta Agriculturae Scandinavica, Section B: Soil and Plant Science, 69 (5): 422-443.

https://doi.org/10.1080/09064710.2019.1593498

4. Benke A. P., Rieps A. M., Wollmann I., Petrova I., Zikeli S., Möller K."2017. Fertilizer value and nitrogen transfer efficiencies with clover-grass ley biomass based fertilizers. Nutrient Cycling in Agroecosystems, 107 (3): 395-411. https://doi.org/10.1007/s10705-017-9844-Z
5. Brock C., Franko U., Oberholzer H.-R., Kuka K., Leithold G., Kolbe H., Reinhold J. 2013. Humus balancing in Central Europe concepts, state of the art, and perspectives. Review article. Journal of Plant Nutrition and Soil Science, 176: 3-11. https://doi.org/10.1002/ipln.201200137

6. Brozyna M. A., Petersen S. O., Chirinda N., Olesen J. E. 2013. Effects of grass-clover management and cover crops on nitrogen cycling and nitrous oxide emissions in a stockless organic crop rotation. Agriculture, Ecosystems and Environment, 181: 115-126.

https://doi.org/10.1016/i.agee.2013.09.013

7. Carter M. S., Sørensen P., Petersen S. O., Ma X., Ambus P. 2014. Effects of green manure storage and incorporation methods on nitrogen release and $\mathrm{N}_{2} \mathrm{O}$ emissions after soil application. Biology and Fertility of Soils, 50: 1233-1246. https://doi.org/10.1007/s00374-014-0936-5

8. Chen Y., Camps-Arbestain M., ShenQ., Singh B., Cayuela M. L. 2018. The long-term role of organic amendments in building soil nutrient fertility: a meta-analysis and review. Nutrient Cycling in Agroecosystems, 111: 103-125.

9. Crews T. E., Peoples M. B. 2005. Can the synchrony of nitrogen supply and crop demand be improved in legume and fertilizer-based agroecosystems? A review. Nutrient Cycling in Agroecosystems, 72 (2): 101-120.

https://doi.org/10.1007/s10705-004-6480-1

10. Dannehl T., Leithold G.. Brock C. 2017. The effect of C:N ratios on the fate of carbon from straw and green manure in soil. European Journal of Soil Science, 68 (6): 988-998. https://doi.org/10.1111/ejss.12497

11. De Notaris C., Rasmussen J., Sørensen P., Olesen J. E. 2018. Nitrogen leaching: a crop rotation perspective on the effect of $\mathrm{N}$ surplus, tield management and use of catch crops. Agriculture, Ecosystems and Environment, 255: 1-11. https://doi.org/10.1016/1.agee.2017.12.009

12. Doltra J., Olesen J. E. 2013. The role of catch crops in the ecological intensification of spring cereals in organic farming under Nordic climate. European Journal of Agronomy, 44: 98-108. https://doi.org/10.1016/j.eja.2012.03.006

13. Doltra J., Gallejones P., Olesen J. E., Hansen S. Frøseth R., B., Krausse M., Stalenga J., Jończyk K., Martínez-Fernándezg A., Pacini G. C. 2019. Simulating soil fertility management effects on crop yield and soil nitrogen dynamics in field trials under organic farming in Europe. Field Crops Research, 233: 1-11. Europe. Field Crops Research, 233: 1-11
https://doi.org/10.1016/j.fcr.2018.12.008

14. Frøseth R. B., Bakken A. K., Bleken M. A., Riley H., Pommeresche R., Thorup-Kristensen K., Hansen S' 2014. Effects of green manure herbage management and its digestate from biogas production on barley yield, $\mathrm{N}$ recovery, soil structure and earthworm populations. European Journal of Agronomy, 52: 90-102. huropean Journal of Agronomy, 32.9006

15. Fortuna A., Harwood R., Kizilkaya K., Paul E. A. 2003. Optimizing nutrient availability and potential carbon sequestration in an agroecosystem. Soil Biology and Biochemistry, 35 (8): 1005-1013. https://doi.org/10.1016/S0038-0717(03)00084-1

16. Gaudin A. C. M. Westra S. Loucks C. E. S., JanovicekK. Martin R. C., Deen W. 2013. Improving resilience of Norther field crop systems using inter-seeded red clover: review. Agronomy, 3 (1): 148-180. https://doi.org/10.3390/agronomy3010148

17. Grant A., O'Donovan J. T., Blackshaw R. E., Harker K. N., Johnson E. N., Gan Y.., Lafon G. P., May W. E., Khakbazan M., Luce M. St. Ramnarine R. 2016 Residual effects of preceding crops and nitrogen fertilizer on yield and crop and soil $\mathrm{N}$ dynamics of spring wheat and canola in varying environments on the Canadian prairies. Field in varying environments on Crops Research, 192: 86-102. 16.04 .019

18. Li X., Petersen S. O., Sørensen P., Olesen J. E. 2015 Effects of contrasting catch crops on nitrogen availability and nitrous oxide emissions in an organic cropping system. Agriculture, Ecosystems and Environment, 199: 382-393. https://doi.org/10.1016/j.agee.2014.10.016

19. Migliorini P. Moschini V., Tittarelli F., Ciacciac C. Benedettelli S., Vazzana C., Canalic S. 2014. Agronomic performance, carbon storage and nitrogen utilisation of longterm organic and conventional stockless arable systems in Mediterranean area. European Journal of Agronomy, 52: 138-145. https://doi.org/10.1016/j.eja.2013.09.017

20. Möller K. 2018. Soil fertility status and nutrient inputoutput flows of specialised organic cropping systems: a review. Nutrient Cycling of Agroecosystems, 112: 147-164 https://doi.org/10.1007/s10705-018-9946-2

21. Nemeikšiene D., Arlauskienè A., Šlepetienè A., CesevičienèJ., Maikštènienè S. 2010. Mineral nitrogen content in the soil and winter wheat productivity as influnced by the pre-crop grasas species and their management. Zemdirbyste-Agriculture 97 (4): 23-36.

22. Nkurunziza L., Marstorp H., Chongtham I. R., Watson C.A. Oborn I., Bergkvist G., Bengtsson J. 2017. Understanding effects of multiple farm management practices on barley performance. European Journal of Agronomy, 90: 43-52. https://doi.org/10.1016/j.eja.2017.07.003 
23. Olesen J. E., Hansen E. M., Askegaard M., Rasmussen I. A. 2007. The value of catch crops and organic manures for spring barley in organic arable farming. Field Crops Research, 100: 168-178. https://doi.org/10.1016/j.fcr.2006.07.001

24. Pandey A., Li F., Askegaard M., Olesen J. E. 2017 Biological nitrogen fixation in three long-term organic and conventional arable crop rotation experiments in Denmark. European Journal of Agronomy, 90: 87-95. https://doi.org/10.1016/j.eja.2017.07.009

25. Povilaitis V., Slepetienè A., Slepetys J., Lazauskas S., Tillvikienè V., Amalevičiūtè K., Feiziené D., Feiza Y., Liaudanskienẻ I., Cesevičienẻ J., Kadžiủlienè Z. KukujevasA. 2016. The productivity and energy potential of alfalfa, fodder galega and maize plants under the conditions of the nemoral zone. Acta Agriculturae Scandinavica, Section B: Soil and Plant Science, 66 (3): 259-266. Section B: So1 and Plant Science, 66 (3): 259-266.
https://doi.org/10.1080/09064710.2015.1093651

26. Preissel S., Reckling M., Schläfke N., Zander P. 2015. Magnitude and farm-economic value of grain legume precrop benefits in Europe: a review. Field Crops Research, 175: 64-79. https://dol.org/10.1016/j.fcr.2015.01.012

27. Räberg T., Carlsson G., Jensen E. S. 2018. Nitrogen balance in a stockless organic cropping system with different strategies for internal $\mathrm{N}$ cycling via residual biomass. Nutrient Cycling of Agroecosystems, 112: 165-178. http://doi.org/10.1007/s10705-018-9935-5

28. Raudonius S. 2017. Application of statistics in plant and crop research: important issues. Zemdirbyste-Agriculture, 104
(4): $377-382$. https://doi.org/10.13080/z-a.2017.104.048

29. Rong G., Ning Y., Cao X., Su Y., Li J., Li L., Zhou, D. 2018. Evaluation of optimal straw incorporation characteristics based on quadratic orthogonal rotation combination design. The Journal of Agricultural Science, 156 (3): 367-377. https://doi.org/10.1017/S002185961800028X

30. Sorensen J. N., Thorup-Kristensen K. 2011. Plant-based fertilizers for organic vegetable production. Journal of Plant Nutrition and Soil Science, 174 (2): 321-332. https://doi.org/10.1002/jpln.200900321

31. Sørensen P. Kristensen E. Odokonyero K., Petersen S. O. 2013. Utilization of nitrogen in legume-based mobile green manures stored as compost or silage. Løes A-K. et al. (eds) NJF Seminar 461, organic farming systems as a driver for change. NJF Report. Nordic Association of Agricultura Scientists, vol. 9, p. 157-158.
32. Šarūnaitė L., Kadžiulienė Ž., Deveikyte I., Kadžiulis L. 2013. Effect of legume biological nitrogen on cereals grain yield and soil nitrogen budget in bi-cropping system. Journal of Food Agriculture and Environment, 11 (1): $528-533$.

33. Thorup-Kristensen K., Dresbøll D. B., Kristensen H. L. 2012. Crop yield, root growth, and nutrient dynamics in a conventional and three organic cropping systems with different levels of external inputs and $\mathrm{N}$ re-cycling through fertility building crops. European Journal of Agronomy, 37 : 66-82. https://doi,org/10.1016/i.eja.2011.11.004

34. Tripolskaja L., Sidlauskas G. 2010. The influence of catch crops for green manure and straw on the infiltration of atmospheric precipitation and nitrogen leaching. Zemdirbyste-Agriculture, 97 (1): 83-92.

35. Valkama E., Lemola R., Kankanen H., Turtola E. 2015. Meta-analysis of the effects of undersown catch crops on nitrogen leaching loss and grain yields in the Nordic countries. Agriculture, Ecosystems and Environment, 203: 93-101. https://doi.org/10.1016/j. agee.2015.01.023

36. van der Burgt G. J. H. M., van Eekeren N., Scholberg J., Koopmans C. 2013. Lucerne (Medicago sativa) or grassclover as cut-and-carry fertilizers in organic agriculture. Grassland Science in Europe, 18: 123-125.

37. van Opheusden A. H. M., van der Burgt G. J. H. M., Rietberg P. I. 2012. Decomposition rate of organic fertilizers: effect on yield, nitrogen availability and nitrogen stock in the soil. Louis Bolk Institute, $40 \mathrm{p}$.

38. Volungevič̣ius J. Feiza V., Amalevič̣iūtè-Volungè K., Liaudanskienè I., Šlepetienè A., Kuncevičius A., Vengalis R., Vèlius G., Prapiestienè R., Poškienè J. 2019. Transformations of different soils under natural and anthropogenized land management. Zemdirbyste-Agriculture, 106 (1): 3-14. https://doi.org/10.13080/z-a 2019.106.001

39. Watson C. A., Reckling M., Preissel S., Bachinger J., Bergkvist G., Kuhlman T., Lindström K., Nemecek T., Topp C. F. E., Vanhatalo A., Zander P., Murphy-Bokern D.' Stoddard F. L. 2017. Grain legume production and use in European agricultural systems. Advances in Agronomy, 144: 236-303. https://doi.org/10.1016/bs.agron.2017.03.003

40. WRB. 2014. World reference base for soil resources. World Soil Resources Reports No. 106. FAO, p. 187-189.

41. Zydelis R., Lazauskas S., Volungevičius J., Povilaitis V. 2019. Effect of organic and mineral fertilizers on maize nitrogen nutrition indicators and grain yield. ZemdirbysteAgriculture, 106 (1): 15-19.

https://doi.org/10.13080/z-a.2019.106.002

ISSN 1392-3196 / e-ISSN 2335-8947

Zemdirbyste-Agriculture, vol. 107, No. 1 (2020), p. 17-24

DOI 10.13080/z-a.2020.107.003

\title{
Augalinès kilmès organinių trąšų įtaka vasarinių miglinių javų derliui ir azoto panaudojimui ekologinio ūkininkavimo sistemoje
}

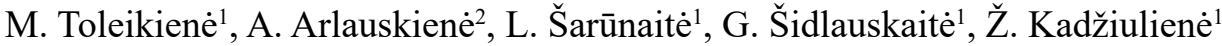 \\ ${ }^{1}$ Lietuvos agrarinių ir miškų mokslų centro Žemdirbystès institutas \\ ${ }^{2}$ Lietuvos agrarinių ir miškų mokslų centro Joniškèlio bandymų stotis
}

\section{Santrauka}

Augalininkystės sistemose pupiniai augalai yra pagrindinis azoto $(\mathrm{N})$ tiekimo, maisto medžiagu apykaitos, pasèliu produktyvumo ir dirvožemio derlingumo elementas. Lauko eksperimentai buvo vykdyti 2015-2017 m. sunkaus ir vidutinio sunkumo priemoliuose dviejose eksperimentinèse vietovėse Lietuvoje. Tyrimo tikslas - ištirti dvejų metu technologiškai apdorotu augalinès kilmès organinių trąšu itaką dirvožemio mineralinio $\mathrm{N}$ bei judriuju humuso medžiagų kiekiui ir vasarinių miglinių javų produktyvumui bei $\mathrm{N}$ kaupimuisi ekologinèje augalininkystès sistemoje. Buvo tirtos šios augalinès kilmès trašsos: šviežia raudonuju dobilu biomasè, fermentuota raudonuju dobilų masè, fermentuota žirnių ir kviečių masè, kompostuota raudonųjų dobilų ir kviečių šiaudų masė bei granuliuotas galviju méšlas. Nustatyta, kad šviežioje ir fermentuotoje raudonuju dobilu biomasèje gausu $\mathrm{N}$ ir kalio (K), kompostuotoje raudonujų dobilų ir šiaudų masèje - fosforo (P). Dirvožemio mineralinio N kieki pirmaisiais metais reikšmingai didino šviežiu raudonuju dobilu masè, antraisiais - fermentuotu raudonuju dobilu masè, be to, jis reikšmingai koreliavo su augalinių trąšų C:N santykiu. Pirmaisiais metais vasarinių kviečių grūdų derlius buvo esmingai didesnis panaudojus šviežių raudonujų dobilų masę ir granuliuotą galvijų mėšlą; antraisiais metais vasariniu miežiu grūdu derliu labiausiai didino fermentuotu raudonuju dobilu masè. Per dvejus tyrimo metus, tręšiant augalinėmis organinėmis trąšomis, abiejuose eksperimentuose didesnis javų grūdų ir šiaudų N kiekis buvo sukauptas naudojant šviežius raudonuosius dobilus, fermentuotus raudonuosius dobilus ir granuliuota galviju méšlą. Palyginus dviejų eksperimentų rezultatus, augalinių trąšų įtaka javų produktyvumui ir dirvožemio cheminès sudèties pokyčiams buvo efektyvesnè mažai mineralinio $\mathrm{N}$ turinčiame vidutinio sunkumo priemolyje, palyginus su turinčiu daugiau mineralinio N sunkiu priemoliu. Fermentuotų raudonujų dobilų ir granuliuoto galvijų mėšlo itaka buvo panaši, tačiau didesniu efektyvumu pasižymėjo fermentuota raudonųų dobilų masè vidutinio sunkumo priemolyje ir granuliuotas galvijų méšlas sunkiame priemolyje.

Reikšminiai žodžiai: C:N, dirvožemis, fermentuota biomasè, humusas, kompostas, raudonieji dobilai. 